\title{
Teachers' Turnover: What Are The Explanatory Variables in Public Secondary Schools in Mbeere South Sub-County, Embu County, Kenya?
}

\author{
Mr. Katula John M. Mutune ${ }^{1}$, Prof.John Aluko Orodho ${ }^{2 *}$ \\ Doctorate Student, Department of Educational Management, Policy and Curriculum Studies, School of \\ Education, Kenyatta University, Kenya \\ Associate Professor (Specialist in Research and Statistics) Department of Educational Management, Policy and \\ Curriculum Studies, School of Education, Kenyatta University, Kenya
}

\begin{abstract}
The thrust of this study was to examine the main explanatory variables for the rapid teachers' turn over in public secondary schools in Mbeere South Sub-County, Embu County Kenya. The study was premised on in investment Human Capital Theory, proposed by Becker (1993). The objectives of the study were threefold, namely to: analyse school management policies, the attitude of teachers, and personal characteristics of teachers on rate of turnover among teachers in public secondary schools in Mbeere sub- county, Embu County. A descriptive survey research design was adopted. Combinations of purposive and random sampling techniques were used to select 29 principals and 120 teachers yielding a total sample size of 149 participants. A questionnaire, piloted prior to data collection to determine its validity and reliability, was used as the main research instrument. In-depth interview with principals corroborated and complimented data generated through questionnaires. The main findings were that the teacher turnover was high and fluctuating having increased from $4.27 \%$ in 2009 to $8.21 \%$, in 2010 and marginally decreased to $7.2 \%$ in 2011 . The main reasons for the high teachers' turn over were: job dissatisfaction among teachers as results of poor motivation and remuneration, limited avenues for promotions and professional growth due to unsupportive school and government policies. It was recommends that the Government of Kenya through the Ministry of Education and Salaries and Remuneration Commission should put in place functional teacher professional development strategies and enhanced remuneration initiatives to enhance their efficiency, productivity and reduce current turnover; amongst others.(249 words).
\end{abstract}

Key Words: Teacher turnover, professional development, teacher motivation, retention, public secondary schools, Mbeere sub-county, Embu County, Kenya.

Background of the Study

\section{Introduction}

There is abundant literature which has made an attempt to diagnose the state high teacher turnover in several developed countries such as Herbert and Ramsay ( 2004) in United States, Finlayson (2003) in Scotland and Santiago (2001) in Britain with some of the studies reporting teacher turnover having reached national crisis (BBC News Online, 2001). Santiago (2001) reported that the teacher turnover situation in Sweden, Germany and New Zealand had become worse. Similarly, studies from the USA are not any better, with teacher shortages as a result of turnover being widely reported in many states (Markley, 2001; Rohr \& Lynch, 1995; Colbourne, 1998; Ingersoll, 2002).

In developing countries, the problem of teacher turnover is comparatively serious. A study by Xaba, (2003) in South and other African countries such as Zambia and Malawi indicated that the problem of teacher turnover had almost reached a calamitous stage. Evidence exists to show that most African countries are grappling with serious teacher shortages due to high turnover rates. In Lesotho, Urwick, Mapuru \& Nkhoboti (2005) established high levels of turnover especially in rural remote areas, noting that remote rural schools cannot attract qualified teachers, except for the head teacher. As a consequence, unqualified teaching staff account for over one-third of the staff of the schools in Lesotho, but less than five percent in the capital, Maseru (Urwick et al, 2005). In Sierra Leone, Harding and Mansaray (2005) demonstrated that high rates of turnover have led to an acute shortage of qualified teachers in rural areas, which is the most serious staffing weakness, which prevents rural children receiving quality education. These researchers indicated that most rural schools in Sierra Leone have only one or two qualified teachers (Harding \&Mansaray, 2005). In Malawi according to Kadzamira (2005), there is a glaring urban bias in the distribution of (educational) resources. Low job satisfaction makes it very difficult to staff rural schools properly. Remote rural schools are chronically understaffed due to high teacher turnover and the refusal of teachers to be deployed to schools in these areas. In the 
hard to staff remote schools, once a teacher is lost through attrition, it is very difficult to find a replacement (Kadzamira, 2005). These researchers all concur that there is a serious problem of teacher turnover in developing countries, especially in rural remote areas.

In the Kenyan context, the situation of high teacher turnover is not any different from the global and regional trends (Orodho, 2013). Not only is there a shortage of qualified teachers in Kenyan secondary schools, but also teachers are leaving the profession to take up non-teaching employment (Oketch \& Ngware, 2012; Orodho, 2013). Reports from the Kenya National Union of Teachers (KNUT) indicate that there is a high rate of teacher turnover in the country. For example, Oyaro (2008), quoting data from KNUT, reported that between January and June 2008, six hundred teachers had left classrooms in Kenyan schools for better paying jobs elsewhere. That is about three teachers leaving the service every day. The Republic of Kenya/UNESCO (2012) end of Decade evaluation of education in Kenya lamented that although the pupil teacher ratio at the national level may show that the country has achieved the recommended ratio of 45:1, there are still regional disparities in the Coast and North Eastern provinces, where the pupil teacher ratio can be as high as 53:2 and 63:1 in 2007 respectively. Despite the efforts of the government to recruit teachers, the teacher shortage still persists (Orodho, 2013). The national teacher shortage stands at 61,235 for both primary and secondary schools (Republic of Kenya/UNESCO, 2012). It is arguable that the loss of qualified teachers from the profession for any reason affects Kenya's economic development, particularly in the scientific, technological, and professional sectors, and objective which the Government of Kenya is striving to achieve through education (Republic of Kenya, 2012a, 2012b). It is against this background that this study set out to investigate the status of the teacher turnover and examine some of the explanatory variables for the teacher turnover in public secondary schools in Mbeere Sub-County, Embu County, Kenya,

\section{Status of the Teaching Profession}

\section{State Of The Art Review}

There is growing evidence that have attempted to explore the challenges confronting teacher education, possible explanatory variables for the high teacher turn over as well as development of teacher education in Africa (Ondaro,2004; Oplatka,2007; Orodho,2013; Republic of Kenya,2012a,2012b; Robinson \&Latchem, 2003; Thiongo ,2008; Tirop,2011; Yee,1990). Some of the challenges relate to: the growing gap between the demand and supply of teachers especially in science and mathematics; the increasing demand for better quality teachers and teacher education; the need for social and professional regulation in relation to quality assurance; the challenges of cross border education; advances in Information Communication Technologies (ICTs) and the resultant need for leveraging modern ICTs in the training of teachers; pressure for national competitiveness in a globalized knowledge-based economy against an existing reservoir of untrained and under trained teachers in many African countries; and, the inability of the traditional residential university model of teacher education and training to adequately meet either current or projected demand for teacher education (Robinson \& Latchem, 2003). Among these challenges, teachers' turnover has been given the least attention in the country. Tirop (2011) discloses that teaching is still the poorest paying jobs in the country. Quality teachers cannot be retained under the current terms and conditions of service. According to Ondara (2004) most of the teachers who either decline to take up teaching positions in Government -aided schools, deserted or resigned were mainly Science oriented teachers. These cadres of teachers feel they can be paid much better if they worked in the private sector or other ministries, other than Teachers' Service Commission (Orodho, Waweru, Getange \& Miriti, 2013).

According to Oplatka (2007) teaching profession was one of the few respected jobs open to Africans before independence; and thus it was considered to be a noble profession then in Kenya. In many respects, the teacher was regarded as a leader to be consulted on many issues as he was seen as a source of knowledge; thus a teacher was viewed as a dependable member of society and consequently commanded respect from students and the public. After independence, the teaching profession degenerated to such low levels that it was no longer attractive to most of the gifted people. Thiong'o (1987) observes that the teacher has become a caricature, the object of constant ridicule and ribald jokes by both the pupils and the public.

Oyaro (2008) notes that teachers leave the classroom to work in a variety of fields - in the media, financial institutions, private academies, non-governmental organizations and insurance companies. Many are also leaving the teaching frontline for jobs with the Ministry of Education as Quality Assurance and Standards Officers, where terms of service are more lucrative than the Teachers' Service Commission (TSC) offers.

\section{Competitiveness of Labour Market}

Previous studies have looked into the various factors that cause labour turnover. According to Weru (1984), labour turnover is caused by availability of new employment opportunities of employment in the competitive sector; personality clash between the worker and the supervisor; transfer of organization misfits from one department to another; when an organization changes its operation system leading to reduction in 
manufacturing of a product hence loss of jobs and where the worker decided to take an early retirement. The worker is enticed by the retirement package (Weru, 1984).

A variety of factors affect teachers' decisions to remain in the classroom. Herzberg (1968) identified factors that influenced job satisfaction or dissatisfaction, and noted that employees with high levels of job dissatisfaction have high intentions to quit. In pre-independence Kenya, the teaching profession was one of the few respected jobs open to Africans; and thus it was considered to be a noble profession then. In many respects, the teacher was regarded as a leader to be consulted on many issues as he/she was seen as a source of knowledge; thus a teacher was viewed as a dependable member of society and consequently commanded respect from students and the public. After independence, the teaching profession, which was considered noble, degenerated to such low levels that it was no longer attractive to the most gifted people. Researchers have indicated that the low status, poor remuneration, constant ridicule in public and the mass media, the lack of fringe benefits, overwork, and deplorable working conditions, have created a lot of despair amongst teachers. The powers given to the board of governors on the recruitment, supervision and discipline may in practice increase the turnover intentions of contracted teachers, while demoralizing the serving teachers. In actual sense, there is a great disparity in the terms and the conditions of service in the institutions. This suggests that most of the teachers in our schools are there because of lack of alternatives, but not because of teaching career commitment.

Yee (1990) examined how teachers arrive at career decisions and how building-level context issues may affect these career decisions and therefore teacher retention. Yee identified two broad categories, "good-fit" and "weak-fit" teachers, as measures of initial reasons for which individuals chose teaching as a career. "Goodfit" teachers were described as those who knew all along that they wanted to be teachers. Their reasons were "a desire to work with young people, a commitment to service, an interest in teaching a particular subject, or inspiration from a teacher". These reasons fit the "satisfiers" or "motivator" factors identified by Herzberg (1966). "Weak-fit" teachers are described as those who chose the job by default. The job was initially considered a temporary position, one to carry the individual for a few years until something else more appealing came along. These two descriptions are divided further to describe career patterns: "good-fit stayers, good-fit undecideds, good-fit leavers, weak-fit stayers, and weak-fit leavers" (Yee, 1990).

As defined by teacher interviews in Yee's (1990) study, good-fit stayers began teaching expressing a "strong commitment to social change and a desire to work with young people". Strong collegial and administrative support beginning with the first year of teaching helped provide positive imprinting to carry the teachers through the difficult times that occurred during their ensuing career. Continuous professional development and involvement supported the good-fit teachers as they shared their belief that teaching well is an on-going task. Yee found that generally teachers became good-fit stayers as a result of "positive workplace experiences that yield sufficient intrinsic rewards".

Good-fit undecided, like the good-fit stayers, entered teaching with similar philosophies. Classroom conditions such as large classrooms, behaviour management, student absences, and lack of student progress led to a sense of failure with students and were noted as reasons for dissatisfaction. One interviewee in Yee's (1990) study pointed to "the administrative atmosphere as a significant source of stress and ambivalence". With extrinsic rewards, which do not counter balance the weakened intrinsic rewards, potentially good-fit stayers are good-fit undecided's, teetering on the see-saw of whether to stay or leave the classroom. Good-fit leavers also began teaching with positive reasons. Yee found their initial attitudes changed as a result of both intrinsic and extrinsic rewards in the workplace experiences. Shifts in the academic focus, reduced fiscal resources, out-offield teaching assignments, inadequate administrative and collegial support, and students' behaviours were cited as the workplace factors that led to their leaving the classroom and teaching (Yee,1990).

As a group, weak-fit stayers became teachers because "they fell into it or simply had nothing better to do". Beyond this similarity, Yee (1990) pointed out these teachers subdivide into two groups, high-involvement and low-involvement teachers. High-involvement teachers credit their workplace conditions with their transformation. For some weak-fit stayers, their beginning teacher success became a reality due to the support and reinforcement of strong and positive administrative and collegial assistance. The extrinsic rewards of pay, vacation, and benefits ranked lower than the intrinsic rewards of working with students for the high-involved, weak-fit stayers. Low-involvement teachers differed from the high-involvement teachers in that they spent as little time as possible on the job. They remained in teaching for the extrinsic rewards. Vacation days and scheduling allowed time to be with family or to be involved in other personal pursuits. Classes were taught with minimal preparation with the same lessons repeated year after year. Lack of enthusiasm was noted as a hallmark of the low-involvement weak-fit stayer.

Weak-fit leavers began teaching with the same reasons as the weak-fit stayers. They were identified by themselves and by administrators as someone whose heart was not in teaching. Traumatic first year experiences with little to no help from administrators and colleagues, being assigned to different subject areas, lack of 
professional stimulation, unsatisfactory workplace conditions, and poor performing students were reasons weakfit leavers shared for their decision to leave teaching.

Yee (1990) concluded that retaining teachers is a process that begins with induction into the profession. It is a process which requires "nurturing through administrative and collegial support of teaching conditions and competence". Again, the importance of supporting teachers' extrinsic needs as exemplified by building-level context variables and their intrinsic needs and interests as proposed by Herzberg (1966) is illustrated through research.

A critical focus on Kenya's education system could give some insight on the most likely factors that could be influencing the mass exodus of teachers; and which have worsened the staffing situation in schools; with an intention to tame the situation. It constitutes an 'Internal brain drain' with negative effects on learning in schools. The analysis and the assessment of such factors are based on: Ministry of Education and Teachers Service Commission (TSC) policy related factors; teacher characteristic policy related factors and school management policy related factors. These factors formed the basis of reasoning, in assessing those that were relevant in Mbeere South District and could be influencing the secondary school teachers' turnover. Literature was reviewed according to the following sub-headings.

\section{School and School Management related factors}

Okumbe (1998) says workers are concerned with their working environment for their personal comfort as well as facilitating their efficiency at work. Omamo (1971) ascertains that a majority of the teachers work in the rural areas in Kenya because $80 \%$ of the County' population live there. This scenario agrees with the present school location situation in Kenya. Mbeere South District; being an ASAL land is a typical example. The location of most schools in the interior rural settings with poor or inadequate infrastructure lower the morale of most teachers working there. The Teachers' Service Commission (TSC) makes it mandatory for a teacher to stay in the station for at least five years before a genuine transfer is given; again, it is a prerequisite for a teacher to teach in any school were his/her services are required. Several teachers have become victims to such circumstances ranging from insecurity, hostile climates, too much workloads and overwork beyond measure; and some cases related to natural attrition including sickness and death. Management policy related factors have ranged from signing of performance contracts, intimidation of teachers in pursuit for promotion and challengeable and unwell thought interdiction of teachers.

\section{Teacher characteristic related factors}

These include gender, professional qualifications, teaching experience, social-cultural factors, job satisfaction and career commitment. Studies have shown that gender is a strong facet of an employee job satisfaction. Most teachers teaching in rural areas and especially women face difficult climatic and cultural problems. They prefer staying with their spouses against the policy of a teacher balancing.

With respect to professional qualifications, Kimengi's (1983) study proved professional variable to have no influence on attitudes of teachers towards teaching. Okumbe (1992) study showed the variable to have had some influence. The levels of satisfaction among graduate teachers increase with their professional level. Dubin (1978) postulates that job satisfaction increases with the skills required to work. With current retirement age of teachers having been pegged at 60 years, majority of teacher in schools could be approaching the ceiling age. Teachers' turnover could adversely affect education systems in the districts disproportionately: with the worst hit being those districts with majority of young teachers. Researchers have proved that aged people have low turnover intention as they have more family pressures than young people; in this context, teachers.

\section{Teaching Experience}

With regards to teaching experience, studies have established that the level of job satisfaction and motivation among the workers increases with job experience. Reyes (1990) study indicated that work orientation was related to the degree of job satisfaction among teachers. This means that job satisfaction increase with experience in teaching. Schultz and Schultz (1986) argue that age and experience in the job usually bring with it greater competence, self-confidence, self-esteem and a higher level of responsibility in which a person may feel a greater sense of accomplishment. It is now 15 years since employment of teachers was frozen . The Teachers' Service Commission (TSC) has since been replacing those who leave out of interdiction, death, sickness and retirement. It is to be noted that majority of the teachers in the service are approaching the age of 60 years; since they, either had been newly employed in 1963 or were employed by then. Again the 235,000 ceiling of the total number of teachers is not enough as put by the Teachers' Service Commission (TSC) Chairman Mr. Hussein. This logically implies that majority of those teachers leaving the teaching job are young teachers who should be retained in the job; if Kenya is to realise its quality education, vision 2030, as implied by Prof. Douglas Odhiambo task force to analyse the implementation of the new constitution on education, training and research for national development (Republic of Kenya, 2012a, 2012b). 
Other factors are related to job satisfaction and include: poor remuneration - very low wage or salary causing search for greener pastures; lack of job security causing workers to look for a serious employer; domination of labour in an organization by the largely unstable middle class; and, industrial fatigue leading to decline in production of goods, low market or demand of company's products and subsequent closure of operations (Drucker, 1999). Over the last, several years studies have been carried out on job satisfaction within school set ups. Maslow's Hierarchy of Needs and Hertzberg's Two-Factor Theory have been extensively utilized to the study of teachers' job satisfaction. Such studies include Sergiovanni and Claver (1967). In Kenya; they include Ngaroga (1985); Okumbe (1987); Immonye (1990); Sogomo (1993) and Mumo (2000). Those studies have indicated that teachers stay on the job if physical, social status, economic and security aspects associated with the conditions of their work are satisfactory. The studies further suggest that adequate provision of salary, proper working conditions, and good supervision, teaching materials, small classes, preparations, time and premium pay prevent job dissatisfaction. A scrutiny of these factors if not present in a working place lowers the morale of the teachers, leading to the turnover intentions; whose eventuality results into critical turnover. The Kenya National Union of Teachers (KNUT) calls such inadequacies "insensitivity with the Teachers employer"; KNUT- Secretary General while addressing the issue of contracting teachers calls such inadequacies "slavery" logically implying that teachers dissatisfaction is very high and any slight employment opportunity elsewhere will spark a lot of competition from applicant teachers. He adds that teaching job is the poorest paid job in the country.

Finally, researchers have for long sought to understand the factors associated with employees' career commitment to remain in a given career or switch careers, as well as factors that influence labour turnover. For example, Meyer and Lynne (2001) came up with the concept of career commitment, which refers to the identification with, and involvement in, one's occupation. A person with a high career commitment is likely to remain in that career than one with low career commitment. Meyer and Allen (1991) proposed the concept of organizational commitment, arguing that decisions to remain in or quit an organization depend on how an employee is to that organization.

\section{Policy related factors}

The education Act 211, gives the Minister for Education authority to promote education in the country. It is worthwhile to note that the Minister is a politician in nature and sometimes make pernicious policies which may have political influences like appointment of BOG members and promotion of teachers which are likely to be skewed; Section 3: part II; Promotion of some educational development plans which may see teachers being put under policies which are intimidating, high-handedness, insensitive, KNUT (2012).

According to Tyson \& York (2000), workers can resign from their jobs as a result of employers failing to institute professional counseling to their employees to enable them adjust to their jobs' internal and external environment. Sexual harassment is another cause as it exists in organizations and to some it is part of the organization culture. Women employees who are often the victims of this vice from their seniors prefer to leave the job.

The revised code of regulations, revised with the approval of the Minister for Education under Section 6(1) of the Teachers' Service Commission Act (Cap. 212, Laws of Kenya) is a document used in schools to govern the conduct of teachers during their service delivery. The policies that are put in place to govern the teachers have had adverse effects namely: The policy on study leave and the associated penalties; Education News (February 17 - March 2, 2012); unfavorable transfers; policy on promotion of teachers as put by James Kiyapi; Education News; February 17 - March 2, (2012); Stagnation of teachers in one job Group; Teachers' Service Commission Authorities; Terms of service and employment of teachers and failure to remunerate teachers as agreed between the Teachers Service Commission Remuneration Committee and the Kenya National Union of Teachers; which has bled insensitivity on the part of the employer; as put by KNUT secretary (Dan Oloo, 2012).

\section{Statement of the Problem}

The problem of high teacher turnover continues to beleaguer the education sector in Kenyan has been demonstrated by several researchers and institutions (Orodho, 2013) The Government of Kenya acknowledges the magnitude of the problem but merely states that the current demand-driven recruitment policy was put in place to address the uneven distribution of teachers and teacher shortages ( Republic of Kenya/UNESCO,2012). The Republic of Kenya/UNESCO (2012) further counsels that due to the freeze on new recruitment, the commission has only been replacing teachers who leave the service through natural attrition. The truth on the ground is that there is an acute shortage of teachers and a dire growing need for more teachers to cope with higher demand following the implementation of free primary and free day secondary education, where the government provides for free tuition fees among other factors. In 2010, in an effort to bridge the gap in teacher 
shortage, the government recruited 18,060 teachers on contract terms as a temporary measure to alleviate the teacher shortage. In 2011/2012 financial year, these teachers were given permanent positions.

There is a problem of labour turnover among the teachers in public secondary schools in Kenya, especially those working in rural areas. For example, at least $4 \%$ of teachers working in Mbeere South District have been looking for opportunities to move to schools in urban settings (Statistics from District Education Office Mbeere South District, 2011). Although the Kenya government encourages teachers to remain in hardship areas by providing fringe benefits, most teachers working in such areas feel that what is offered is too little compared to what their counterparts in urban areas make on the side by engaging in businesses. These factors could lead to lack of devotion for teachers working in rural areas as is evident in their instability in the teaching profession and low morale in performing their teaching tasks and consequently unsatisfactory performance in daily school duties and responsibilities. Teachers including those who are working on contract terms have been leaving teaching job for better pastures, despite the implementation of hardship allowance by the Teachers' Service Commission (TSC) to seal the loopholes left by the defecting professionals. The central problem for this study is to understand the teacher exodus and explanatory factors which influence secondary school teachers' turnover in Mbeere South Sub-County, Embu County, Kenya.

\section{Purpose of the Study and Objectives of the Study}

The purpose of the study was to analyse the factors that influence secondary school teachers' turnover in Mbeere South District .The Objectives of the study were to:

1. Analyse the rate of turnover among secondary school teachers in Mbeere South Sub-County, Embu County, Kenya.

2. Establish how school management policies influence turnover among the secondary school teachers in Mbeere South Sub-County, Embu County, Kenya.

3. Find out the attitude of teachers towards school principals and their influence in turnover in Mbeere South Sub-County, Embu County, Kenya.

4. Examine personal characteristics of teachers associated with turnover among secondary school teachers in Mbeere South Sub-County, Embu County, Kenya.

\section{Theoretical Framework}

This study used the Human Capital Theory of Occupational Choice proposed by Becker (1993). Human capital theory of occupational choice provides a framework for an understanding of some underlying factors that may contribute to an individual's decision to become a teacher, and subsequently, to remain in or leave teaching. The theory illustrates the relationships among education and training, migration and the search for a new job in terms of investment and its returns (Becker, 1993). One of the major principles of human capital theory of occupational choice is that the greater the amount of knowledge and skills accumulated in a job over time from investments in education and job training, the lower one's probability of turnover from that occupation (Ehrenberg \& Smith, 2003).

Expected utilities from turnover decisions are influenced by entry requirements to the profession, and future benefits such as better salary (monetary rewards), working conditions (non-pecuniary attribute), and professional training benefits. If the present value of the benefits associated with turnover exceeds the costs, individuals are more likely to make a decision to change jobs. The present value of the net benefits of turnover (that is, the benefits minus the costs) will be larger under the following conditions: greater is utility derived from the new job; less happiness derived from the job of origin; and smaller immediate costs associated with change (Ehrenberg \& Smith, 2003).

From the perspective of human capital theory, monetary benefits (such as health insurance, pensions) from the teaching profession can be viewed as returns on investment (ROI) in education and training. Such returns may make individuals more productive, resulting in higher wages and the trade-offs associated with the costs (Becker, 1993). Generally speaking, if teachers feel that their return is being lowered as they work, they will be less likely to invest in teaching and thus leave. In other words, teachers who have perceived that they have put too much into teaching but have not gotten enough in return decide to leave (Becker, 1993).

Along with monetary benefits, teachers consider non-monetary benefits as one of the most important factors affecting their career decisions. In general, non-monetary benefits may include support from fellow teachers and administrators, the quality of school facilities and resources available, autonomy in classroom, participation in school decision-making, student learning attitudes, and assigned teaching hours. Most of the literature refers to these non-monetary benefits as working conditions. Working conditions vary by school type, location, and demographics of students, teachers and parents (Becker, 1993).

Individuals increase their store of human capital through formal schooling and on-the-job training which includes induction programs and professional development programs. Training as investment in human capital can be labeled as general or specific. General training that accumulates generic human capital can be 
defined as any training that can be easily transferred to other professions and can increase an individual's future wages or benefits (Kirby \&Grissmer, 1993). In contrast, specific training that builds up firm-specific human capital can be defined as training which is specific to the school in which a teacher teaches or another school (Kirby \& Grissmer, 1993).

\section{Research Design}

III. Research Design And Methodology

The descriptive survey design was used in this study. This design was chosen because it involves collecting data in order to answer questions concerning the current status of the subjects of the study with a view to understand the distribution, intensity, and interrelationships between the study variables (Orodho, 2009a, 2012). Survey design was appropriate for this study because it enabled the researcher to collect information concerning the current situation in public secondary schools in Mbeere South District as regards turnover intentions of teachers and make possible conclusions from the findings of the study.

\section{Target Population and Sample Size}

Orodho (2009a) defines population as a group of individuals from which samples are taken for measurement. The target population for this study comprised of all the 319 classroom teachers and 29 principals in all the 29 secondary schools in Mbeere South District. Of the 29 public secondary schools, 2 were girls boarding, 2 were boys boarding, 1 mixed boarding, 10 mixed day and boarding and 11 mixed day schools. Stratified sampling technique was used to select participating schools according to school type, that is, girls boarding, boys boarding, mixed day, mixed day and mixed boarding schools. Stratified sampling technique was chosen because it guaranteed desired representation of relevant sub-groups thus increasing the representativeness of the sample compared to the population Orodho, 2012). For each stratum, $66.7 \%$ of the total number of schools was sampled which is in line with Gay's (1992) recommendation. Stratified random sampling was used to select 20 principals from the sampled schools while random sampling was used to select 120 classroom teachers ( 6 per school), giving a total of 140 participants.

\section{Data Collection and Analysis}

The study employed a questionnaire and an interview schedule as the main research instruments for data collection. Questionnaires were administered to the 120 teachers who participated in the study. Gay (1992) maintains that questionnaires give respondents freedom to express their views or opinion and also to make suggestions. Items in the questionnaire were both open and closed ended. Borg and Gall (1989) emphasize that whereas the open ended type of questions give informants freedom of response, the close ended type facilitate consistency of certain type of data across informants. Interview schedules required collecting data from school principals of the sampled secondary schools..

Before the actual data collection, piloting of the data collection instruments was done on three secondary schools, which did not participate in the final study. Piloting enabled the researcher to test the reliability of the questionnaire. The researcher used the pilot study to identify items in the questionnaire/interview schedule that would have been ambiguous or unclear to the respondents and change them effectively. Validity is the degree to which results obtained from the analysis of the data actually represents the phenomena under study. According to Borg and Gall (1989), validity of an instrument is improved through expert judgment. As such, the researcher sought the assistance of research experts, experienced graduates, lecturers and experienced supervisors in order to help improve validity of the instrument. The test-retest method was used to test the reliability of the questionnaires. Questionnaires were given to the 6 teachers in the pilot school, and results analyzed. After a period of two weeks, the same instruments were again given to the same 6 teachers, and results analyzed. Using the Spearman -Brown prophecy formula, the scores of the first and second administrations were computed and a correlation coefficient of 0.823 was obtained indicating that the instruments were reliable. A reliability coefficient of 0.7 or above was accepted as recommended by Orodho (2012).

A research permit was obtained from the National Commission for Science, Technology and Innovation (NASCOSTI) before proceeding to collect data. After this, the researchers booked an appointment with the principals of the sampled schools to administer the questionnaire to the principals and teachers. The researchers then visited each of the sampled schools and administered the questionnaires himself. As the teachers filled the questionnaires the researcher conducted a face-to-face interview with the principals as guided by the interview schedule. The respondents were given instructions and assured of confidentiality after which they were given enough time to fill in the questionnaires. Quantitative data from questionnaires were analyzed with the aid of the Statistical Package for Social Sciences (SPSS) Computer package version 20, and descriptive statistics generated. This was in line with the Orodho (2009b) analytical plan for analyzing quantitative data. It was also consistent with Martin and Acuna (2002) who counsel that SPSS is able to handle large amount of 
data, and given its wide spectrum of statistical procedures purposefully designed for social sciences, it is quite efficient. The qualitative data from in-depth interviews were analyzed through interview transcriptions and thematic analysis.

\section{Findings and Discussion}

\section{Effects of School Management Policy on Teachers' Turnover}

The first objective sought to establish from the principals how the Board of Management policy on teachers' discipline influences turnover among the secondary school teachers in the District. To establish this, the respondents were given a list of items in a table regarding possible causes of teachers' turnover. They were required to state the extent to which management policy issues cause turnover among teachers on a three-point Likert scale. The scale ranged from 1-3 with 1 denoting not at all likely to cause turnover, 2 representing somehow likely to cause turnover while 3 very likely to cause turnover. The mid-point of the scale was a score of 2. Therefore, any score above 2 denoted that teacher management issues were likely to cause turnover while scores below 2 denoted that teacher management issues were not at all likely to cause turnover. Table 1 illustrates mean scores and standard deviations obtained.

As shown in Table 1 the mean scores obtained on teachers on management issues ranged from 2.64 to1.92. Majority of the respondents obtained scores above 2 in all management policy issues except on the aspect of the BOM policy on teachers' discipline, meaning that most of the management policy issues were likely to cause teachers' turnover. Specifically, approximately two thirds of the teachers reported that the main teacher management policy issues that were very likely to cause teacher turnover included; the amount of salary that the teachers receive $(74.2 \%)$, the opportunity available for them to grow professionally $(66.7 \%)$ and the opportunities available for their promotion by the TSC $(64.2 \%)$.

In addition, the study respondents further indicated that working conditions in the school where the teachers taught $(22.5 \%)$, teachers' workload and the BoG policy on teachers' discipline $(32.5 \%)$ were other factors that influenced teachers' turnover. To verify these findings, more than $60 \%$ of the principals gave the following reasons for teachers' turnover: Low salary, denying teachers the opportunities for success and in search for better working conditions. This therefore implies that due to low salaries and other motivational benefits, teachers are said to be dissatisfied with their work and consider leaving their jobs for greener pastures. For instance, non-promotion among teachers was one of the factors contributing to high rate of labour turnover.

In agreement with the findings, Drucker (1999) found out that teachers turnover was due to poor remuneration - very low wage or salary causing search for greener pastures; lack of job security causing workers to look for a serious employer; domination of labour in an organization by the largely unstable middle class; and, industrial fatigue leading to decline in production of goods, low market or demand of company's products and subsequent closure of operations.

Table 1 : Teacher management policy issues

\begin{tabular}{|c|c|c|c|c|c|c|c|c|}
\hline \multirow[t]{2}{*}{$\begin{array}{l}\text { Statement } \\
\mathrm{N}=120\end{array}$} & \multicolumn{2}{|c|}{$\begin{array}{l}\text { Very likely to } \\
\text { cause turnover }\end{array}$} & \multicolumn{2}{|c|}{$\begin{array}{c}\text { Somehow likely } \\
\text { to cause } \\
\text { turnover }\end{array}$} & \multicolumn{2}{|c|}{$\begin{array}{l}\text { Not at all likely } \\
\text { to cause } \\
\text { turnover }\end{array}$} & \multirow[t]{2}{*}{ Mean } & \multirow[t]{2}{*}{$\begin{array}{l}\text { Std. } \\
\text { Deviation }\end{array}$} \\
\hline & f & $\%$ & f & $\%$ & f & $\%$ & & \\
\hline $\begin{array}{l}\text { The amount of salary I receive } \\
\text { for my work }\end{array}$ & 89 & 74.2 & 19 & 15.8 & 12 & 10.0 & 2.64 & .658 \\
\hline $\begin{array}{l}\text { The opportunity available for } \\
\text { teachers to grow professionally }\end{array}$ & 80 & 66.7 & 30 & 25.0 & 10 & 8.3 & 2.58 & .643 \\
\hline $\begin{array}{l}\text { The opportunities available for } \\
\text { promotion by TSC }\end{array}$ & 77 & 64.2 & 31 & 25.8 & 12 & 10.0 & 2.54 & .672 \\
\hline $\begin{array}{l}\text { The teacher appraisal system } \\
\text { used by the TSC }\end{array}$ & 66 & 55.0 & 39 & 32.5 & 15 & 12.5 & 2.42 & .706 \\
\hline $\begin{array}{l}\text { The concern that the TSC } \\
\text { shows for teacher welfare }\end{array}$ & 64 & 53.3 & 37 & 30.8 & 19 & 15.8 & 2.38 & .745 \\
\hline $\begin{array}{l}\text { The way the TSC officials } \\
\text { handles teachers' grievances }\end{array}$ & 51 & 42.5 & 48 & 40.0 & 21 & 17.5 & 2.25 & .736 \\
\hline $\begin{array}{l}\text { The opportunity afforded to } \\
\text { me to choose the district where } \\
\text { I wish to work as a teacher }\end{array}$ & 50 & 41.7 & 34 & 28.3 & 36 & 30.0 & 2.12 & .842 \\
\hline $\begin{array}{l}\text { The working conditions in the } \\
\text { school where I teach }\end{array}$ & 46 & 38.3 & 47 & 39.2 & 27 & 22.5 & 2.16 & .767 \\
\hline
\end{tabular}


Teachers' Turnover: What Are The Explanatory Variables in Public Secondary Schools in Mbeere

\begin{tabular}{lcccccccc}
\hline $\begin{array}{l}\text { The workload I have as a } \\
\text { teacher }\end{array}$ & 44 & 36.7 & 37 & 30.8 & 39 & 32.5 & 2.04 & .834 \\
$\begin{array}{l}\text { The BoG policy on teachers, } \\
\text { discipline }\end{array}$ & 30 & 25.0 & 51 & 42.5 & 39 & 32.5 & 1.92 & .758 \\
\hline
\end{tabular}

Similarly, Maicibi (2003) too conducted studies on factors of job satisfaction among teachers in selected schools and like other researchers he found out that poor pay had ranked as the first factor that contributes to teacher turnover. Because of this and more, the Monitor Newspaper (28th March 2003) wrote an article "who will wipe away the tears of teachers?" in which poor pay was pointed out as one of the major factors affecting teacher turnover. The problem of teacher turnover is mainly caused by poor pay among other factors as Blair and Jordan (1999) emphasize that academic staffing has been undermined by large outflows of staff to other sectors of the economy, and it is most probable that it is the well trained and more experienced teachers who leave schools for better employment opportunities leaving a vacuum to be occupied by the less experienced or poor quality teachers.

\section{Teachers' Attitudes towards School Principals}

The second objective sought to find out how the attitude of teachers towards school principals influence teachers' turnover in Mbeere South District. To answer this question, teachers were given a list of items in a table regarding their principals' leadership. They were required to state their agreement levels on a three-point Likert scale Table 2 shows their responses. They were required to state the extent to which leadership policy issues cause turnover among teachers on a three-point Likert scale Table 2 shows the mean scores and standard deviations obtained.

As shown in Table 2 the mean scores obtained on principal leadership policy issues ranged from 2.04 to1.76. Scores above two denoted that principals' leadership issues were very likely to cause turnover while scores below 2 denoted not at all likely to cause turnover. Results in the table revealed that majority of the respondents obtained scores below 2 in most aspects. However, it is evident that aspects on principals' leadership style obtained high scores.

Moreover, $37.5 \%$ of them were of the views that the approach used by principals during staff appraisal was another factor which somehow influenced teachers' turn over. On the other hand, a notable number of the respondents reported that the willingness of principals to help teachers obtain study leave (43.3\%), allocation of duties/lessons for teachers and the willingness of the principal to assist teachers solve personal problems (45.0\%) were factors that were not likely to cause turnover of teachers.

It therefore emerged that the leading factor of teacher turnover regarding their attitude towards their principals was principals' leadership styles. School principal had a responsibility of ensuring that teachers employed are satisfied with their jobs. This can be achieved through effective communication, provision of instructional resources and offering support services e.g. in professional developments and also solving personal problems. However, if teachers' expectations are not met, this would lead to subsequent drop in the commitment and a possible withdrawal of cooperation of job as a whole. 
Table 2: Principals' Leadership Policy Issues

\begin{tabular}{|c|c|c|c|c|c|c|c|c|}
\hline \multirow[t]{2}{*}{$\begin{array}{l}\text { Statement } \\
\mathbf{N}=120\end{array}$} & \multicolumn{2}{|c|}{$\begin{array}{l}\text { Very likely to } \\
\text { cause turnover }\end{array}$} & \multicolumn{2}{|c|}{$\begin{array}{c}\text { Somehow } \\
\text { likely to cause } \\
\text { turnover }\end{array}$} & \multicolumn{2}{|c|}{$\begin{array}{c}\text { Not at all } \\
\text { likely to cause } \\
\text { turnover }\end{array}$} & \multirow[t]{2}{*}{ Mean } & \multirow[t]{2}{*}{$\begin{array}{c}\text { Std. } \\
\text { Deviation }\end{array}$} \\
\hline & f & $\%$ & $\mathbf{f}$ & $\%$ & f & $\%$ & & \\
\hline $\begin{array}{l}\text { The leadership style employed by my } \\
\text { principal }\end{array}$ & 54 & 45.0 & 30 & 25.0 & 36 & 30.0 & 2.15 & .857 \\
\hline $\begin{array}{l}\text { The interpersonal relationship between the } \\
\text { principals and the teachers }\end{array}$ & 45 & 37.5 & 35 & 29.2 & 40 & 33.3 & 2.04 & .844 \\
\hline $\begin{array}{l}\text { The support given by principals to teachers for } \\
\text { professional development }\end{array}$ & 43 & 35.8 & 39 & 32.5 & 38 & 31.7 & 2.04 & .824 \\
\hline $\begin{array}{l}\text { The approach used by principal during staff } \\
\text { appraisal }\end{array}$ & 38 & 31.7 & 45 & 37.5 & 37 & 30.8 & 2.01 & .794 \\
\hline $\begin{array}{l}\text { The satisfaction I get in the way my work is } \\
\text { appreciated by the principal }\end{array}$ & 40 & 33.3 & 38 & 31.7 & 42 & 35.0 & 1.98 & .830 \\
\hline $\begin{array}{l}\text { The willingness of the principal to involve } \\
\text { teachers in decision making }\end{array}$ & 36 & 30.0 & 43 & 35.8 & 41 & 34.2 & 1.96 & .803 \\
\hline $\begin{array}{l}\text { The extent to which the principal makes } \\
\text { teachers feel part of a team }\end{array}$ & 34 & 28.3 & 45 & 37.5 & 41 & 34.2 & 1.94 & .792 \\
\hline $\begin{array}{l}\text { Willingness of the principals to employ BoG } \\
\text { teachers to reduce workload }\end{array}$ & 37 & 30.8 & 33 & 27.5 & 50 & 41.7 & 1.89 & .848 \\
\hline $\begin{array}{l}\text { The willingness of principals to help teachers } \\
\text { obtain study leave }\end{array}$ & 33 & 27.5 & 35 & 29.2 & 52 & 43.3 & 1.84 & .830 \\
\hline Allocation of duties/lessons for teachers & 29 & 24.2 & 37 & 30.8 & 54 & 45.0 & 1.79 & .809 \\
\hline $\begin{array}{l}\text { The willingness of the principal to assist } \\
\text { teachers solve personal problems }\end{array}$ & 25 & 20.8 & 41 & 34.2 & 54 & 45.0 & 1.76 & .778 \\
\hline
\end{tabular}

The findings are consistent with Okumbe (1998) who suggests that principals as supervisors should be conversant with various theories of work motivation and job satisfaction in order to be effective in influencing subordinates. If the worker deems the supervisory leader unworthy and incompetent, it becomes frustrating to them thus producing job dissatisfaction (Flippo, 2009). One of the employee's wants that contribute to motivation and job satisfaction is competent fair leadership (Flippo, 2009). Good leadership ensures that psychological and security needs for workers are adequately met.

\section{Personal Characteristics of Teachers Associated with Turnover}

The final objective sought to examine personal characteristics of teachers associated with turnover among teachers. To answer this question, the respondents were given items in a table regarding their personal characteristics. They were required to state their agreement levels on a four-point Likert scale. The scale ranged from 1-4 with 1 denoting strongly disagree, 2 disagree, 3 denoting agree while 4 strongly agree. The mid-point of the scale was a score of 2.5 . Therefore, any score above 2.5 denoted teachers agreed with the statements based on the feelings towards their jobs while scores below 2.5 denoted that teachers disagreed with the statements. Table 3 illustrates mean scores and standard deviations obtained.

As shown in Table 3, approximately one third of them were of the views that the approach used by principals during staff appraisal was another factor which somehow influenced teachers' turn over. On the other hand, a notable number of the respondents reported that the willingness of principals to help teachers obtain study leave (43.3\%), allocation of duties/lessons for teachers and the willingness of the principal to assist teachers solve personal problems $(45.0 \%)$ were factors that were not likely to cause turnover of teachers' mean scores obtained on teachers' attitude towards their job ranged from 3.03 to1.76.

Responses from the table show that over $70.0 \%$ of the respondents agreed (combined strongly agree and agree) that: teachers would advise close relatives/friends to join the teaching profession (72.5\%), sometimes they feel they would wish to change their career (76.7\%) and if given a chance they would take up a job not related to teaching $(75.8 \%)$. 
On the other hand, the respondents disagreed (combined strongly disagree and disagree) that: they preferred to teach in schools in an urban setting (50.9\%), they had seriously considered switching careers (73.3\%) and that they reported to work just because of the money they received, otherwise they did not enjoy teaching $(84.2 \%)$. This was an indicator that the teachers had a negative attitude towards teaching. It also implied that most of the teachers were not satisfied with their career and this was one of the factors influencing their effectiveness in work performance and as a result leading to turnover.

Table 3 : Teachers' feelings towards their job

\begin{tabular}{|c|c|c|c|c|c|c|c|c|c|c|}
\hline Teachers' feelings & & $\mathbf{A}$ & & $\mathbf{A}$ & & D & & D & & Std. \\
\hline $\mathrm{N}=120$ & $\mathbf{F}$ & $\%$ & $\mathbf{f}$ & $\%$ & $\mathbf{f}$ & $\%$ & $\mathbf{f}$ & $\%$ & Mean & Deviation \\
\hline $\begin{array}{l}\text { Sometimes I feel I would wish to change my } \\
\text { career }\end{array}$ & 38 & 31.7 & 54 & 45.0 & 22 & 18.3 & 6 & 5.0 & 3.03 & .840 \\
\hline $\begin{array}{l}\text { If given a chance, I would take up a job not } \\
\text { related to teaching }\end{array}$ & 39 & 32.5 & 52 & 43.3 & 19 & 15.8 & 10 & 8.3 & 3.00 & .907 \\
\hline $\begin{array}{l}\text { I would wish to move from this school to } \\
\text { teach in a different school }\end{array}$ & 34 & 28.3 & 47 & 39.2 & 31 & 25.8 & 8 & 6.7 & 2.89 & .896 \\
\hline $\begin{array}{l}\text { I would advise a close relative/friend to join } \\
\text { the teaching profession }\end{array}$ & 26 & 21.7 & 61 & 50.8 & 25 & 20.8 & 8 & 6.7 & 2.88 & .826 \\
\hline $\begin{array}{l}\text { I plan to quit teaching sometimes in the near } \\
\text { future }\end{array}$ & 22 & 18.3 & 50 & 41.7 & 32 & 26.7 & 16 & 13.3 & 2.65 & .932 \\
\hline $\begin{array}{l}\text { I prefer to teach in schools in an urban } \\
\text { setting }\end{array}$ & 29 & 24.2 & 30 & 25.0 & 38 & 31.7 & 23 & 19.2 & 2.54 & 1.060 \\
\hline $\begin{array}{l}\text { I joined the teaching profession by choice, so } \\
\text { I have to continue working as a teacher }\end{array}$ & 11 & 9.2 & 31 & 25.8 & 51 & 42.5 & 27 & 22.5 & 2.22 & .900 \\
\hline $\begin{array}{l}\text { I have never seriously considered switching } \\
\text { careers }\end{array}$ & 12 & 10.0 & 20 & 16.7 & 43 & 35.8 & 45 & 37.5 & 1.99 & .974 \\
\hline $\begin{array}{l}\text { I would wish to continue teaching until } \\
\text { retirement }\end{array}$ & 6 & 5.0 & 34 & 28.3 & 31 & 25.8 & 49 & 40.8 & 1.98 & .948 \\
\hline $\begin{array}{l}\text { I report to work just because of the money I } \\
\text { get, otherwise, I don't enjoy teaching }\end{array}$ & 7 & 5.8 & 12 & 10.0 & 38 & 31.7 & 63 & 52.5 & 1.69 & .877 \\
\hline
\end{tabular}

Key: $\mathrm{SA}=$ Strongly agree, $\mathrm{A}=\mathrm{Agree}, \mathrm{D}=$ =Disagree, $\mathrm{SD}=$ strongly disagree

The satisfaction and attitude of teachers are important factors in determining their behavior and responses at work, and it is through these behaviours and responses that minimal rate of turnover can be experienced in the education system and quality education be achieved. In addition, the principals were asked to list some of the unusual behaviors they observed among teachers before tendering their resignation. The following are their responses; Absence- sickness related absence, attending official meetings and family gatherings; poor time-keeping, that is, teachers arriving late and finishing early; teachers left their classrooms during the day; showing signs of sluggishness in attending to their duties and also tended to have a 'don't care' attitude

In relation to the above findings, researchers have indicated that teachers in many of the developing countries such as Gambia, India, Ghana, Kenya, and Pakistan engage in teaching not because of internal motives (such as self-interest, commitment to develop young people), but rather due to external incentives, and, chiefly, a lack of other occupational opportunities in their area (Barrs, 2005; Hedges, 2002).

However, Oplatka (2007), in a review of research, notes that for some teachers in developing countries, mainly female teachers, a career in teaching was viewed as an avenue to service, a noble profession to which people are called. The choice of teaching was often a tangled web of idealism, a love of children, or compliance to entrenched social roles concerning femininity and career indicated by Pakistani female teachers. The family played a key role in the career choice of female Pakistani teachers, whose parents encouraged them to attend teaching training programs (Barrs, 2005). A similar trend was reported by Kenyan female teachers, whereby (Osler, 1997) quoted one woman confessing that as a girl she had not been given a full range of options: "When we were young we were told the best job for a woman is a teacher". 


\section{Conclusion And Recommendations}

The major thrust of this study was to examine some of the explanatory variables for the high turnover of teachers in secondary schools in the study locale. Based on the findings of the study, it can be concluded that most schools in Mbeere Sub-County experience the problem of high teachers' turnover. The main reasons for teachers' turn over were; job dissatisfaction among teachers, poor remunerations and inadequate support from school administration bodies. In relation to school management policies, the study concluded that professional growth; opportunities for promotion and low salaries were the major cause of teachers' turnover. It also emerged that principals' leadership styles and interpersonal relationship among them and teachers negatively influenced teachers' attitude towards teaching hence quitting their job. This was confirmed by majority of the teachers indicating that they feel they would wish to change their career and would take up a job not related to teaching. They further reported that they pursued teaching career because they had no other choice.

Based on the findings presented above, the following recommendations were made;

1. Regarding school management policies, the government through Teachers' Service Commission (TSC) and the Salaries and Remuneration Commission should work together and ensure teachers' remuneration is comparable to their counterparts in the civil service in the same job groups.

2. Concerted effort among all key education stakeholders should be geared towards the enhancement of teacher professional development in order to ensure efficiency, productivity and reduce teacher turnover is attained in Mbeere South Sub-County, Embu County, Kenya.

3. In relation to teachers' attitude towards principals, the study recommends that schools administrators should ensure that leadership styles they apply are friendly to all staff members and other school stakeholders. This would help to promote free expression of opinion among their workers for a sole purpose of increasing confidence and grievance resolution, and therefore control labour wastage.

4. Personal characteristics of teachers associated with turnover, the Ministry of Education should improve working conditions of teachers by providing all the necessary tools for their job and reducing their workload by posting more teachers to schools. This would make teachers feel highly satisfied with their work hence improving their effectiveness in work performance.

5. School managers should seek ways of improving the job satisfaction of teachers. One way of doing this would be to encourage teachers to join professional associations and other forums that would enable them solve career-related problems.

6. Finally, to minimize the rate of turnover among teachers, a concerted effort from all stakeholders (Principals/ BOGs, Ministry of education, Government) in the education system is required.

\section{References}

[1]. Barrs, J. (2005). Factors contributed by community organizations to the motivation of teachers in rural Punjab, Pakistan, and implications for the quality of teaching, International Journal of Educational Development, Vol. 25, 333-48. BBC News Online (18 January 2001). http://news.bbc.co.uk/1/low/education//1124 643.stm

[2]. Becker, G. S. (1993). Human Capital: a Theoretical and Empirical Analysis, with Special Reference to Education. Chicago: The University of Chicago Press.

[3]. Borg, R., W. \& Gall, J. P. (1989).Educational Research. An Introduction (6th Ed), New York: Longman Publishers.

[4]. Croasmum J., Hampton D. \& Herrman S. (2002). Teacher attrition: Is time running out? [Online] Available url: Retrieved June 24, 2011, from

[5]. Colbourne, J. (1998). Teacher turnover. June. Northern News Services. [Online] Available at: http://www.nnsl.com/frames/newspapers/1998-06/jun8_98te ach.html.

[6]. Creswell,J,W.(2003). Research Designs: Qualitative, quantitative, and Mixed Methods Approaches, 2nd Edition, Thousand Oarks, CA, Sage.

[7]. Drucker, P. (1999). Management challenges for the 21st century. New York, NY: Harper Collins.

[8]. Dubin, J. A., (1978). Fundamentals of Organizational Behaviour. An Applied Perspective, (2nd ed). New York: Persimmon Press Inc.

[9]. Dyer, C. (1996). Primary teachers and policy innovation in India: some neglected issues, International Journal of Educational Development, 16 (1), 27-40.

[10]. Finlayson, M. (2003).Improving the wellbeing of teachers in Scotland, Scott. Education Journal, 87(1): 18-19.

[11]. Flippo, S., (2009). "Relationship between Performance Appraisal and Organizational Performance", Google Website, Retrieved April 10, 2011

[12]. Gay, L. R. (1992). Educational Research: Competence for Analysis and Applications. (4th Ed) New York: Macmillan Publishers.

[13]. Greenwood, G. E., \&. Soars, R. S (1973).“Teacher morale and behaviour.” Journal of Educational Psychology, 64: 105-8.

[14]. Grissmer, D., \& Kirby, S. (1997). Teacher turnover and teacher quality. Teachers College Record, 99, 45-56.

[15]. Harding, J. B. \&Mansaray, A. T. (2005). Teacher Motivation and Incentives in Sierra Leone, Division of Educational Studies, University of Sierra Leone.

[16]. Hedges, J. (2002).The importance of posting and interaction with the education bureaucracy in becoming a teacher in Ghana, International Journal of Educational Development, Vol. 22, 353-66.

[17]. Herbert, K. \& Ramsay, M. (2004). Teacher Turnover and Shortages of Qualified Teachers in Texas Public School Districts 2001 2004, Report to the Senate Education Committee, September 2004.

[18]. Herzberg, F. (1968). Work and the Nature of Man. Ohio: The World Publishing Co.

[19]. http://horizon.unc.edu/courses/287/papers/hampton/paper.html

[20]. http://www.nces.ed.gov/pubs/web/95770.asp.

[21]. Ingersoll, R M. (2002). The teacher shortage: A case of wrong diagnosis and wrong perception. NASSP Bulletin, 86. 
[22]. Kadzamira, E. C. (2005) Teacher Motivation and Incentives in Malawi, Zambia: Centre for Education Research and Training, University of Malawi.

[23]. Kimengi, N. L., (1983) 'A Study of Secondary School Teachers' Attitudes towards Teaching and their Job Satisfaction in Kenya'. Unpublished Masters Thesis, University of Nairobi.

[24]. Kenya National Examinations Council, KNEC. (2013, 2014). The Kenya Certificate of Secondary Education (KCSE) Examination results.

[25]. Maicibi, N. A. (2003). Pertinent Issues in Employees management. Kampala MPK Graphics (U) Ltd

[26]. Maicibi, A. (2005). Education an iron curtain. Mash Publisher Kampala.

[27]. Mandera District. (2004). The three years Rolling Development plan 2006/07/08/09 Mandera District, Mandera District Local Government.

[28]. Martin, K. \&Acuna, C. (2002).SPSS for Institutional Researchers. Pennsylvania: Becknell University Press: Lewisburg.

[29]. Meyer, J. P. \& Allen, N. J. (1991).A Longitudinal Analysis of Early Development and Consequences of Organizational Commitment. Canadian Journal of Behavioural Science. 19 (2), 199-215.

[30]. Meyer, J. P. \& Lynne, H., (2001).Commitment in the workplace-Toward a general model. Human Resource Management Review, 47 (3), $23-29$

[31]. Michaelowa, K. (2002). Teacher Job Satisfaction, Student Achievement, and the Cost of Primary Education in Francophone SubSaharan Africa, HWWA Discussion Paper, Hamburg Institute of International Economics

[32]. Mumo, D. (2000). Job satisfaction of Tutors in Technical Training Institutes in Nairobi Province. Unpublished M. Ed. Thesis, Kenyatta University.

[33]. Murnane, R., Singer, J., \& Willett, J. (1988). The career paths of teachers: Implications for teacher supply and methodological lessons for research. Educational Researcher, 17(5), 22-30.

[34]. Okumbe, J. A. (1998). Educational Management Theory and Practice, Nairobi; Nairobi University Press.

[35]. Omamo, O. (1971). The challenge of teachers Education in Rural Transformation: The Kenya Teachers No. R, November.

[36]. Ondara, O. K. (2004). An investigation into job satisfaction among secondary school teachers: A case study of Borabu Division in Nyamira District, Kenya. Unpublished Master of Education Thesis, Kenyatta University.

[37]. Oplatka, I. (2007). The context and profile of teachers in developing countries in the last decade: A revealing discussion for further investigation, International Journal of Educational Management, 21 (6), 476-490.

[38]. Oketch,M. \&Ngware ,M.W (eds.) (2012).urbanization and Education in East n Africa: African Population and Health Research Center. ISBN 978-9966-21-175-0

[39]. Orodho, A.J. (2009a). Elements of Education and Social Science Research Methods: Maseno, Kenya: Kanezja Publishers.

[40]. Orodho, A.J. (2009b). Techniques of Data Analysis Using Statistical Package for Social Sciences (SPSS) Computer Package. Maseno, Kenya: Kanezja Publishers.

[41]. Orodho, A.J. (2012). Techniques of Writing Research proposals in Education and Social Sciences (: Maseno, Kenya: Kanezja Publishers.

[42]. Orodho, A.J.(2014a).The equity and quality of free day secondary education (FDSE) Policy in Kenya: What is the unfinished business in the financial management. .International Journal of Current Research.Vol.8. Issue 03(March, 2014) 5582-5591. http://www.journalcra.com.

[43]. Orodho,A.J.(2014b).Financing Basic Education : What are the equity and quality implications of free primary education (FPE) and Free Day Secondary Education (FDSE) Policies in Kenya? International Journal of Development Research Vol.4 Issue3, pp477487, March,2014.www.journalijdr.com ISSN:2230-9926.

[44]. Orodho, A.J, Waweru, P.N, Ndichu.,\& Nthinguri.(2013).Basic education in Kenya: Focus on strategies applied to cope with school-based challenges inhibiting effective implementation of curriculum. International Journal of Education and Research. Vol 1.No.11 November, 2013 pp1-10.www.ijern.com

[45]. Orodho, A.J., Waweru, P.N., Getange,K.N \& Miriti, J.M.(2013).Progress towards attainment of education for All (EFA) among nomadic pastoralists : Do home-based variables make a difference in Kenya? Research on Humanities and Social Sciences Vol3.No.21, 2013 pp54-67.www.iiste.org

[46]. Oyaro, K. (2008). Education-Kenya: Students Pour In, Teachers Drain Away; Inter Press Service News Agency. Retrieved April 18, 2011, from http://ipsnews.net/africa/nota.asp?idnews=42667.

[47]. Republic of Kenya. (2005a).) Sessional Paper No. 1 on Policy Reforms for Education, Training and Research: Meeting the Challenges of Education Training and Research in the 21st Century. Ministry of Education, Science and Technology (MOEST Nairobi: MOEST.

[48]. Republic of Kenya(2005b). Kenya Education Sector Support Programme 2005 - 2010: Delivering Quality Education and Training to All Kenyans. Nairobi: MOEST.

[49]. Republic of Kenya.(2007a). Gender and Education Policy in Kenya. Government Printer. Nairobi.

[50]. Republic of Kenya. (2007b).Harmonization of the Legal framework on Education Training and Research: A Report of the task force on review and harmonization of the legal framework on education, training and research.

[51]. Republic of Kenya.(2008).Draft report of the Adult and Continuing Education. Government Printers. Nairobi

[52]. Republic of Kenya. (2009a). Policy for Alternative Provision of Basic Education and Training. Ministry of Education Science and Technology. Nairobi.

[53]. Republic of Kenya. (2009b).Policy Framework on Nomadic Education in Kenya. Ministry of Education and UNICEF. Nairobi.

[54]. Republic of Kenya.(2010a). The Constitution of Kenya, 2010. The Attorney General. Nairobi.

[55]. Republic of Kenya .(2010b).Child friendly Schools Manual. Ministry of Education. Nairobi.

[56]. Republic of Kenya.(2012a).Sessional Paper No.14 of 2012 on realigning education and training to the Constitution of Kenya 2010 and Vision 2030 and beyond. Ministry of Education Science and Technology. Nairobi. Kenya.

[57]. Republic of Kenya.(2012b).A Policy Framework for re-aligning education to the Constitution 2010 and Vision 2030 and beyond.

[58]. Republic of Kenya.(2013). The Basic Education Act, 2013 No 14 of 203.The Government Press, Nairobi.

[59]. Republic of Kenya/UNICEF( 2012).Education for All (EFA) End of Decade Assessment (2001 -2010). Ministry of Education and INICEF. Nairobi.

[60]. Reyes, P., (1990). 'Individual Work Orientation and Teacher Outcomes': Journal of Educational Research, 83 (6), p. $227-335$

[61]. Robinson, B., Latchem, C. (Ed) (2003). Teacher Education through Open and Distance Learning; New York: Routledge Falmer.

[62]. Rohr, C. L. \& Lynch H. F. (1995). Migration and attrition of public and private school teachers. Retrieved March 7, 2011, from

[63]. Rothman, E. P. (1981). Troubled Teachers. New York: D. McKay. 
[64]. Santiago, P. (2001). Teacher shortage .Observer $\quad$ OECD.Retrieved $\quad$ May $\quad 14, \quad 2012, \quad$ from http://www.oecdobserver.org/news/printpage.php/aid/431/Teacher_shortage.html.

[65]. Schultz, D. P., and Schultz, S. E., (1986).'Psychology and Industry Today. 'An Introduction to Industrial and Organizational Psychology. (4th ed.). New York: Macmillan Publishing Company.

[66]. Sergiovanni, T. \& Carter, P. (1967).Factors Which Affect Satisfaction and Dissatisfaction. Journal of Educational Administration. $5,66-82$.

[67]. Singleton, R. A. (1993): Approaches to Social Research. NY: Oxford University Press.

[68]. Sogomo, C. K., (1993). Job Satisfaction of Secondary School Principals in the Rift Valley Province of Kenya, Unpublished M.Ed. Thesis. Lakehead University.

[69]. Sylvia, R. D., \& Hutchinson, T. (1985). What makes Ms. Johnson teach? A study of teacher motivation. Human. Relations. 38: $841-56$.

[70]. Thiong'o, G. (1987). A study of the factors that contributes to lack of job satisfaction among primary school teachers in Nyeri municipality of Nyeri District, Unpublished Med Project, Kenyatta University.

[71]. Tirop (2011). "Teaching is still the poorest paying jobs in Kenya." A report by Secondary School Headteachers' Association Chairman.

[72]. UNESCO. (1996). Information and Communication Technologies in Teacher Education: A Planning Guide. Paris: UNESCO.

[73]. UNICEF (1999).The State of the World's Children. New York: UNICEF.

[74]. Urwick, J., Mapuru, P. \&Nkhoboti, M. (2005). Teacher Motivation and Incentives in Lesotho, Maseru: Lesotho College of Education.

[75]. UNICEF). (2002). The state of the world's children's 2000. New York: UNICEF.

[76]. UNESCO. (2005b). Education For All (EFA) Global Monitoring Report. UNESCO, Paris. United Nations (UN). (2004). Millennium development goals: Progress report 2004. Available at www.un.org/millenniumgoals/mdg2004chart.pdf. Retrieved January 25 th 2010

[77]. UNESCO.(2006) Education for All Global Monitoring Report : Literacy for life. Paris.

[78]. United Nations. 2013). A New Global Partnership: Eradicating Poverty and Transform Economy through Sustainable Development. The Report of the High-Level Panel of Eminent Persons on the Post- 2015 Development Agenda. The United Nations.

[79]. UN General Assembly (2002). A World Fit for Children: Annexed to the present resolution. Twenty seven special session: Agenda items, 8 and 9 .

[80]. World Bank. (2008). National Assessment of Education Achievement Vol.1 : Assessing indicators of achievement. Washington D.C.

[81]. World Bank .(2010).World Development Indicators. Retrieved Nov.2010 from http://www.publications.worldbank.org.

[82]. World Bank .(2012).Gender Equity and Development. World Development Reports. Washington D,C. Wright, S. P., Horn, S. P., Sanders, W. L. (1997). Teacher and Classroom Context. Personnel Evaluation in Education, Vol. 11: 57-7.

[83]. Xaba M. I. (2003). Factors influencing the job satisfaction of senior teachers in schools predominantly attended by black students. Med dissertation. Vanderbijlpark: Potchefstroom University.

[84]. Yee, S. M. (1990). Concerns in the Classroom: When Teaching is More than a Job. New York: Teachers College Press. 